\title{
Evaluation of water quantity-quality, floodplain landuse, and land surface temperature (LST) of Turag River in Bangladesh: an integrated approach of geospatial, field, and laboratory analyses
}

\author{
Afsana Hossen Tania ${ }^{1}$ (D) Md. Yousuf Gazi ${ }^{1} \cdot$ Md. Bodruddoza Mia ${ }^{1}$
}

Received: 3 October 2020 / Accepted: 21 December 2020 / Published online: 10 January 2021

(c) The Author(s) 2021 OPEN

\begin{abstract}
Rapid urbanization, industrialization, and development activities are posing numerous threats to the rivers of Bangladesh. In the recent decade, Turag River has been exposed to severe threats due to anthropogenic activities. The present research deals with the evaluation of water quantity-quality, landuse and landcover (LULC), and land surface temperature (LST) of Turag River and its floodplain by using an integrated approach of field study, laboratory analysis, and geospatial techniques. LULC mapping of the study area has been done using multi-temporal Landsat satellite images by unsupervised method, Normalized Difference Vegetation Index (NDVI) and Normalized Difference Water Index indices (NDWI) approach. From LULC classification, the study shows that the average reduction of water bodies from 1989 to 2019 is about $60-66 \%$, and the rate of reduction is about 14.25 ha per year. Due to anthropogenic activities and rapid urbanization, a large number of water bodies have been depleting. The average temperature of the river water from filed observed data is $30.23^{\circ} \mathrm{C}$ and from image processed data is about $28.32^{\circ} \mathrm{C}$. The minimum and maximum values of $\mathrm{pH}$, $\mathrm{EC}$, TDS, and Eh are $6.87-8.44,808-1192 \mu \mathrm{s} / \mathrm{cm}, 406-739 \mathrm{ppm},-31$ to $-150 \mathrm{mV}$, respectively. The concentration ranges of cations ( $\mathrm{Na}, \mathrm{Ca}, \mathrm{Mg}, \mathrm{K}, \mathrm{Fe}$, and $\mathrm{Mn}$ ) are 85.43-247.60, 28.59-39.47, 11.1-13.58, 5.21-13.26l, .07-1.14, .006-.47 mg/l consecutively. The ranges of anions concentration $\left(\mathrm{HCO}^{3-}, \mathrm{Cl}^{-}, \mathrm{SO}_{4}{ }^{2-}, \mathrm{NO}_{3}-\right)$ are 165.45-388.87, 54.81-194.07, 52.49-289.63, 19.63-126.93 mg/l, respectively. It is evident that $\mathrm{HCO}^{3-}, \mathrm{NO}_{3}-$, and $\mathrm{Mn}$ exceed the standard limit of Bangladesh Water Quality Standard (BWQS) and World Health Organization (WHO), indicating that the water of the Turag River is deteriorating that is not safe for human consumption and aquaculture purposes. The study will assist to take some effective measures to control the pollution and uphold the water quality and natural riparian processes. So, the outputs of the study will contribute to the future urban landuse planning in the river floodplain area to mitigate ongoing alarming pollution and unplanned industrialization.
\end{abstract}

Keywords Water quantity · Water quality · Turag River · Satellite images · Landuse · Land surface temperature (LST)

\section{Introduction}

Geographically, Bangladesh is a riverine country with its major Ganges, Brahmaputra, and Meghna (GBM) river system. Except this, numerous small tributaries and distributaries of this major river system are draining throughout the country. River has a vital role in civilization, but unplanned urbanization has been playing a negative impact on the natural processes of rivers. Rivers in Bangladesh also serve people by providing waterways, energy sources, and agricultural activities.

Turag River is a vital channel flowing through the northwestern part of the megacity Dhaka that is geologically located on the south-central region of Madhupur tract and drains toward the southern part of the country [1]. The major landuse along the banks of the Turag River has been

Md. Yousuf Gazi, yousuf.geo@du.ac.bd | 'Department of Geology, University of Dhaka, Dhaka 1000, Bangladesh. 
used mostly for residential and commercial purposes, e.g., bazaars, markets, industries, warehouses, and hospitals. Residents adjacent to the river utilize the river water for swimming, washing, bathing, and boating both for recreation and communication. Water quality and quantity are being deteriorated due to the growing trend of industrialization in Bangladesh, as effluents from these industries discharge directly into the river without any treatment and environmental consideration [2].

A huge amount of industrial waste, sewage, and domestic waste have been dumped into Turag River regularly. Water quality of Turag River is greatly impacted by different industrial discharges including organic and inorganic effluents that interact with river water. This discharge plays an adverse impact on the livelihood of the local community, adjacent landmass, and aquatic ecosystem [3], [4]. Department of Environment [5] declared Turag River as an ecologically critical area (ECA). Whitehead et al. [6] disclosed that Turag-Tongi-Balu River system in Bangladesh is one of the most polluted ones in the world.

Rapid unplanned industrial growth and poor river management practice have been impacting the quality of river water in Bangladesh. Currently, numerous researches have been undertaken to monitor and assess the water quality of different Rivers in Bangladesh [7], [8], [9], [10]. Haque et al. [11] used a metal pollution index to assess the water quality of the Ganges River, Bangladesh. Kabir et al. [12] employed a water quality index along with a statistical approach to evaluate spatiotemporal variations of water quality in the Shitalakhya River, Bangladesh. Islam et al. [13] have investigated the origin and distribution of trace elements in six major river basins, Bangladesh. Nowadays, the issue of the impacts of industrialization on the surface water quality has drawn attention to the researchers of Bangladesh.

Few works have been done by in situ and laboratory analysis of water quality in Turag River. No study conducted using satellite images combined with the laboratory and in situ data. Remote sensing tool is very popular nowadays for environmental monitoring throughout the world. Lee et al. [14] conducted a study on the applications of remote sensing techniques to relate landscape and landuse patterns in watersheds to water quality in South Korea. Zhao et al. [15] documented the LULC influences on water quality in a riverine area near Shanghai, China. Qiao et al. [16] extracted water bodies completely and accurately from the remote sensing image. McFeeters [17] used multi-spectral imagery to denote the presence of surface water by remote sensing techniques.

Nowadays, evaluation and monitoring of the water body and its surrounding area by remote sensing techniques are very popular [18], [19], [20], [21]. Chawla et al. [22] reviewed the use of remote sensing techniques for water security to enhance environmental protection and strengthen water resource management. Shen et al. [23] evaluated the linkage between landscape characteristics and nonpoint source pollution in an urbanized watershed. Tan et al. [24] monitored LST and LULC spatial relationships adjacent to the water body. A precise water quality analysis was done by Somvanshi et al. [25] in Gomti River, Uttar Pradesh. LULC is an important parameter to monitor environmental health in any region [26]. LST in urban areas along with near flood plain areas is a concerning issue for the environmentalist. Recently, several studies focused on the LST of different areas of Bangladesh to monitor spatiotemporal changes [8], [9], [27], [20], [28].

In Bangladesh, surface water quality especially in and around urban areas is deteriorating. Several pieces of research throughout the world concentrated on the surface water security of Bangladesh [29], [30], [31]. Researchers in Bangladesh also played a major contribution to the surface water extent, quality, and quantity monitoring. Water quality mainly traces metal concentration, origin, and distribution of six major river basins of Bangladesh rigorously studied by Islam et al. [13]. Whitehead et al. [32] modeled heavy metal pollution impacted by tannery waste in the Buriganga River system, Bangladesh. Mobin et al. [33] assessed the water quality of the Turag River, Bangladesh, showing the concentration of different physicochemical properties. Aktar and Moonajilin [34] tried to show the impacts of industrial effluents on water quality of Turag River, Bangladesh. Zakir et al. [35] evaluated the pollution due to heavy metals in the waters of Midstream of Karatoa River, Bangladesh. Hydro-environmental pollution of Turag River in Bangladesh rigorously carried out by Islam et al. [36]. Zaman et al. [6] determined the landuse effect on the Turag River water quality. Variation in the water quality of Turag River due to seasonal changes was rigorously studied by Rahman et al. [4].

The study of water quality and quantity of Turag River is very crucial due to the remarkable role of the river in the economic development of Bangladesh like other urban rivers in Dhaka city. Besides, floodplain dwellers are solely dependent on the Turag River for irrigation, drinking, and fishing along with other household activities. The combined approach of remote sensing, field, and laboratory analyses provides a clear scenario of the present status of water scarcity, pollution, and future existence of Turag River. Here, remote sensing data have enabled the study to depict the spatiotemporal changes of the Turag River water and its floodplains landuse and LST. Then, water samples analysis in the laboratory provides the current status of Turag River water quality. Finally, field observations helped to assess the present status of the River and the accuracy of remote sensing study. Water quality is directly related to the LULC of the River floodplains. Similarly, LST 
provides a clue to the environmental deterioration around the floodplains. Hence, integration of the three methods certainly a novel approach to evaluate the water quality-quantity of the River. So, the prime objective of this study is to investigate and monitor the changes of water bodies, LULC surrounding the Turag River, and land surface temperature in and around the river both the quality and quantity of the Turag River using multi-spectral Landsat satellite images from 1989 to 2019.

\section{Study area}

Turag is known as an upper tributary river of the Buriganga, originates from the Bangshi River flows through Gazipur, and meets the Buriganga at Mirpur [37]. The investigated area of Turag River extends from Aminbazar, Savar Upazila to Tongi in Gazipur to Dhaka, Bangladesh (Fig. 1). It is one of the major natural drainage systems in the Gazipur and Dhaka city and one of the most contaminated rivers in Bangladesh having a length of $62 \mathrm{~km}$, and average width is $82 \mathrm{~m}$. The river is draining a part of the Pleistocene terrace, known as Madhupur tract that consists of alluvial soil, mottled red clay [38].

The area, especially river flood plains, is occupied by numerous garments, leather, and food industries, where effluents are discharged by abundant canals into the river. The major sources of pollution in Turag River are garments industries, various consumer goods, tanneries, pharmaceuticals industries, dyeing industries, battery manufacturing, textile, pulp and paper factories, paint, frozen food factories, and chemical factories [39].

\section{Materials and methods}

The study has been performed by a combined approach of field data collection, laboratory analysis, and satellite image-based interpretation. The methodology can be segmented into two-part, satellite image-based analysis, and field-laboratory-based analysis.

\subsection{Satellite image-based analysis}

Five sets of multispectral satellite images of 1989, 2000, 2009, 2015, and 2019 have been collected from the United States Geological Survey (USGS) archive (https ://earthexplorer.usgs.gov/) (Table 1). For the processing, analyzing, and interpretation of satellite images, geospatial software Erdas Imagine 14 and ArcGIS 10.2.2 have been used in the research. For water quantities monitoring, three classification approaches have been used to prepare LULC of the study area. The approaches are the unsupervised classification method using Iterative Self-Organizing Data Analysis Technique or ISODATA, indices based LULC classification, viz. NDVI and NDWI. These three different classification approaches have been used due to the object-oriented accuracy level. Here, unsupervised classification provides a generalized thematic information class in the study area. The NDVI indices emphasize the vegetation changes that have been used to observe the spatiotemporal variation in vegetation cover. Besides, NDWI indices have been used to evaluate the changes in the water bodies in and around Turag River. The combination of three provides a conspicuous picture of the total LULC changes in the study area. To monitor the remote sensing-based water quality and adjacent flood-plain area, LST has been retrieved for the selected years (Fig. 2).

NDVI has been calculated utilizing the following equation [40]:

$N D V I=\frac{N I R-R E D}{N I R+R E D}$

where NIR = reflectance value in near infrared region; RED $=$ reflectance value in red region

The NDVI value ranges from -1 to +1 . The densely vegetated region shows positive values around +1 , whereas water body shows value close to -1 .

NDWI has been calculated using the following equation defined by McFeeters [41]:

$N D W I=\frac{\text { GREEN }-N I R}{\text { GREEN + NIR }}$

where GREEN = reflectance of green region; NIR = reflectance of near infrared region

The NDWI values also range from -1 to +1 . Positive values signify water features, while vegetation and soil typically show zero and negative values.

\subsection{Field-laboratory analysis}

To assess the in situ water quality of Turag River water, several physicochemical parameters and major ions have been studied in the hydro-geochemistry laboratory, Department of Geology, University of Dhaka. A total of 14 water samples were collected with GPS locations from the Turag River by boat. To meet this purpose, in situ $\mathrm{pH}$, Eh and temperature have been recorded with a HANNA pocket $\mathrm{pH}$ meter (model $\mathrm{HI}$ 98127). Electrical conductivity and total dissolved solids (TDS) have been measured with an OAKTON waterproof pocket $\mathrm{pH}$-EC comb Meter (model PC tester 35). Cations $\left(\mathrm{Na}^{+}, \mathrm{K}^{+}, \mathrm{Ca}^{2+}, \mathrm{Mg}^{2+}, \mathrm{Fe}\right.$, and $\mathrm{Mn}$ ) and heavy metals are identified by atomic absorption spectrometer (AAS) (GBC SensAA) and anions $\left(\mathrm{Cl}^{-}, \mathrm{NO}^{3-}\right.$, 


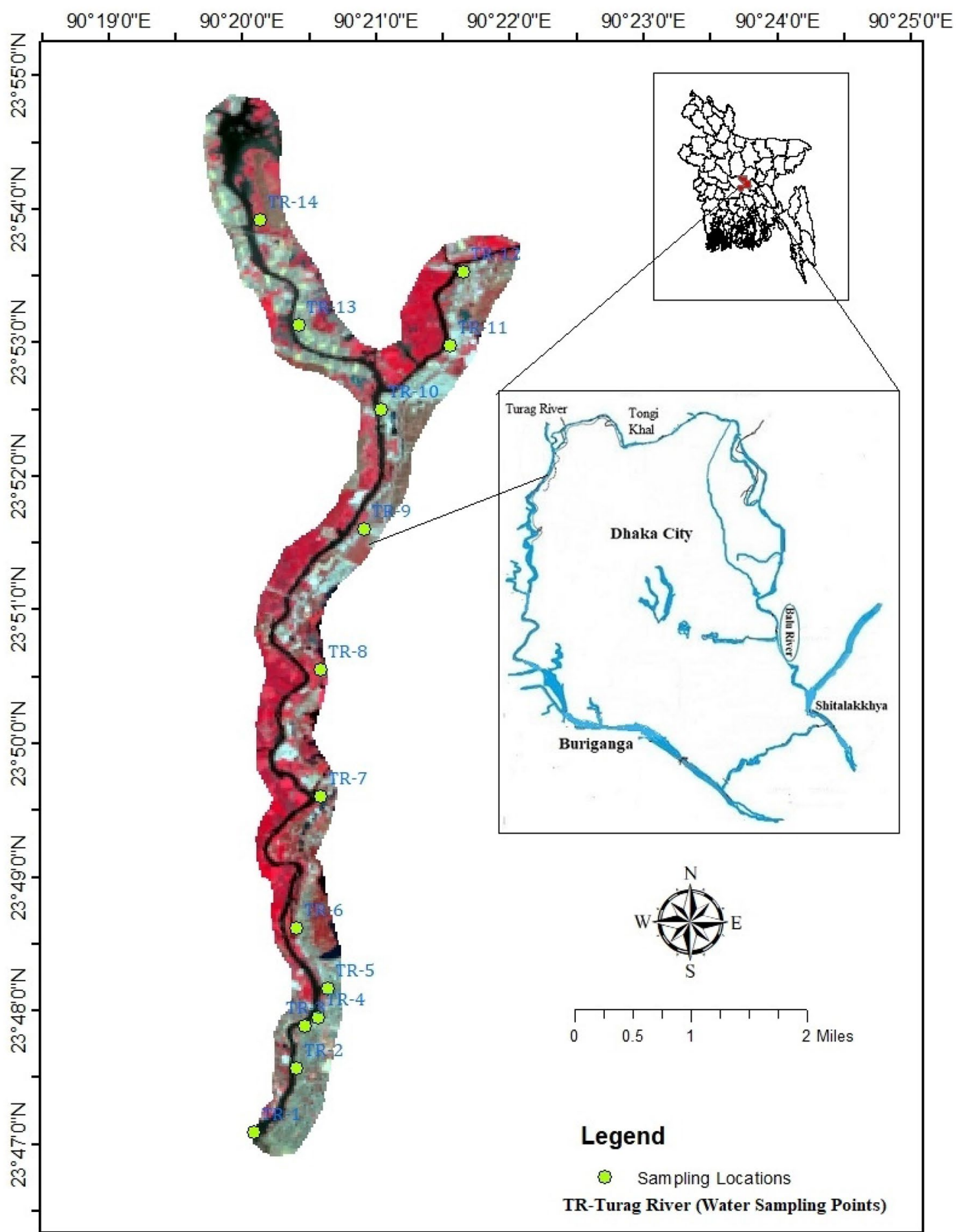

Fig. 1 Location and extent of the study area. The background is the band combination of Red: Green: Blue = Band 5: Band 4: Band 3 of Landsat 8 images dated 2018

$\mathrm{SO}^{2-}, \mathrm{F}^{-}, \mathrm{Br}_{-}$, and $\mathrm{PO}^{3-}$ ) by ion chromatography system (DIONEX).

\subsection{Accuracy assessment}

To determine the accuracy of the retrieved LULC classes from the satellite images, an accuracy assessment has 
Table 1 Satellite images specifications with their acquisition dates

\begin{tabular}{lllll}
\hline Sensor platform & Projection & Acquisition date & $\begin{array}{l}\text { Resolution of } \\
\text { used bands }\end{array}$ & WRS path and row \\
\hline Landsat 5 (TM) & UTM, Zone 46 WGS 84 & $09 / 03 / 1989$ & 30 & $137 / 44$ \\
& UTM, Zone 46 WGS 84 & $19 / 01 / 2000$ & 30 & $137 / 44$ \\
& UTM, Zone 46 WGS 84 & $28 / 02 / 2009$ & 30 & $137 / 43$ \\
Landsat 8 (OLI/TIRS) & UTM, Zone 46 WGS 84 & $17 / 03 / 2015$ & 30 & $137 / 43$ \\
& UTM, Zone 46 WGS 84 & $24 / 02 / 2019$ & 30 & $137 / 43$ \\
\hline
\end{tabular}

Water quantity monitoring \& quality evaluation

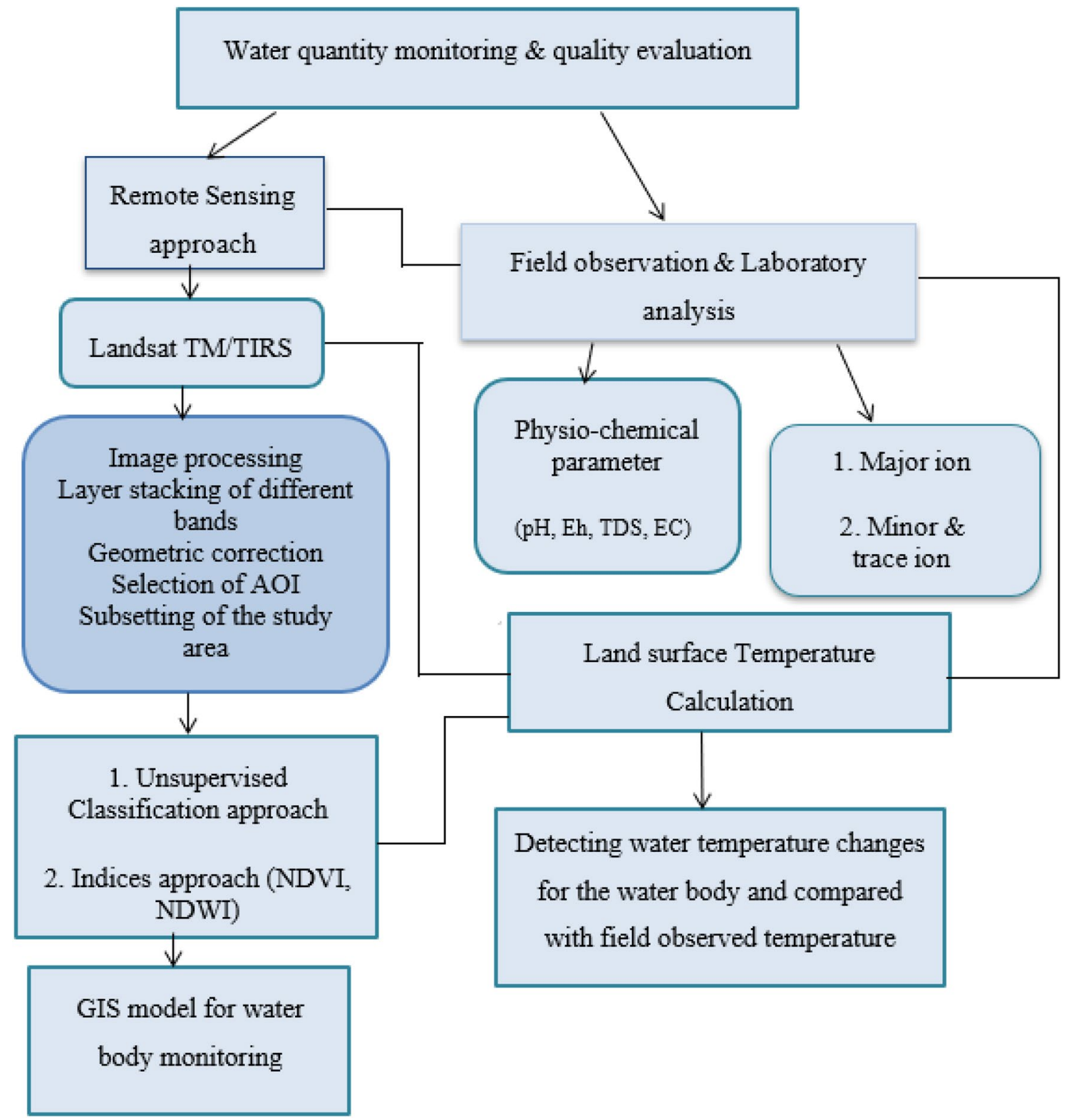

Fig. 2 Methodology flowchart of the study

been performed. The ground observation data with the observed LULC have been taken as reference data. The unsupervised classified image of 2019 has been compared with these ground truth data. The observed point's coordinates have been converted to ASCII format, and each point is compared with the reference value of 
the classified image of 2019. Overall average classification accuracy is about $86.67 \%$ determined from the kappa statistics value.

Accuracy assessment has also been done for satellite-based LST measurement. Here, field measured values compared with all satellite images retrieved LST for the year of 2019. The water temperature of in situ measurements has been compared with the satellite image-retrieved LST and found a similar trend among 14 ground observation points of the Turag River. Satellite image-retrieved LST data values were lower than field observed in situ LST because the satellite images are medium resolution (resampled $30 \mathrm{~m}$ ) and always give an average pixel value.

\section{Results and discussion}

\subsection{Landuse-landcover (LULC) mapping}

\subsubsection{LULC by unsupervised classification approach}

A total of five LULC classes of the study area have been classified such as water bodies, vegetation, bared, and urban area. From unsupervised classification, it has been identified that water bodies reduced about 50\% from 1989 (about 405 ha) to 2019 (about 205 ha). There has been a gradual decrease in the water bodies from 1989 to 2019 (Fig. 3). There are two probable reasons for the reduced water bodies on both sides of the Turag River during the study period such as (1) filled up and development for the housing project, and (2) conversion of those water bodies

LULC Map by Unsupervised Classification from 1989 to 2019

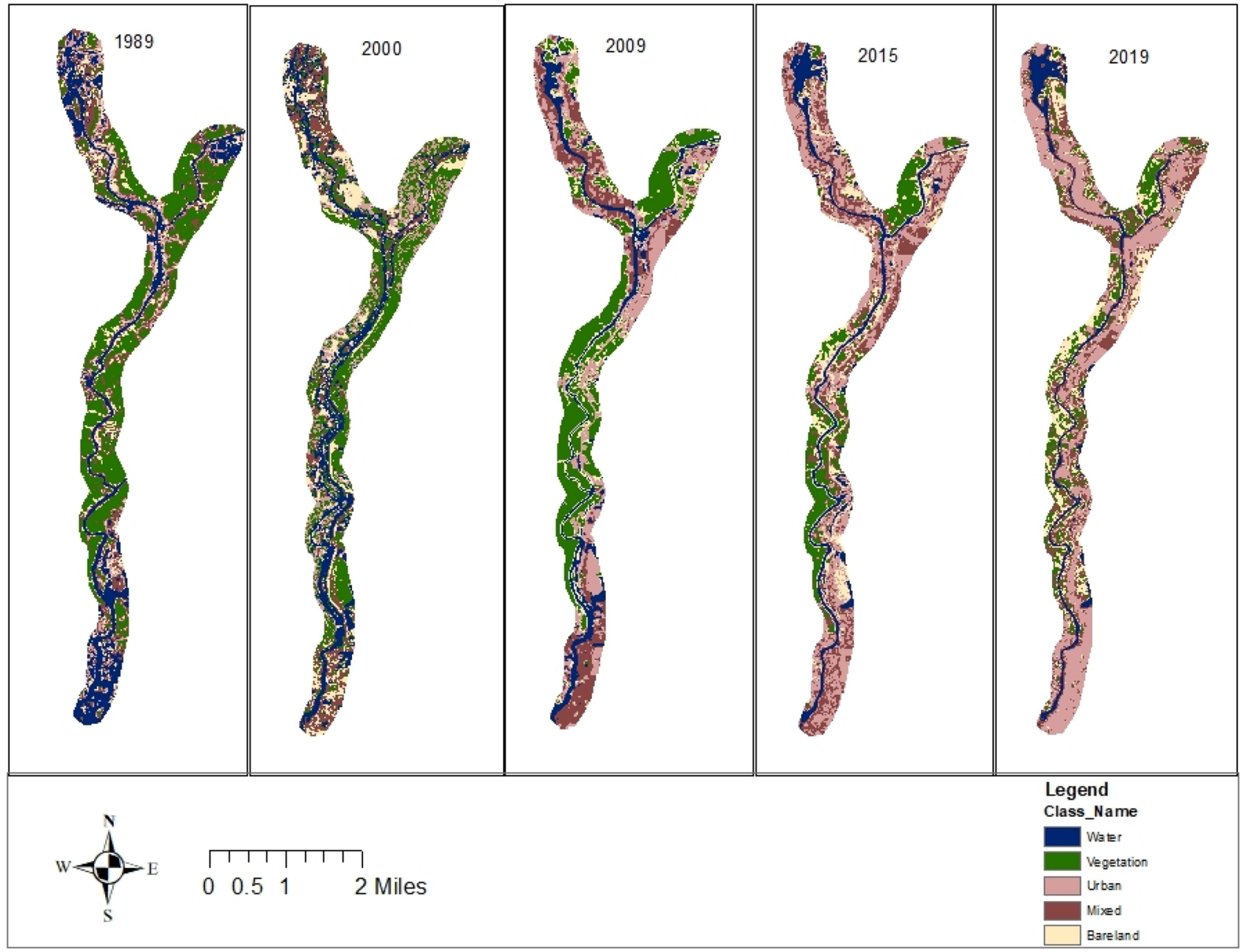

Fig. 3 Spatial distribution of LULC from 1989 to 2019 by Unsupervised Classification Approach 
into agricultural land due to reduced water flows or other development activities like brickfield.

There had also been a rapid degradation of vegetated lands throughout the study period. Vegetation cover reduced gradually more than $50 \%$ from 1989 ( $600.53 \mathrm{ha}$ ) to 2019 (242.72 ha). The losses of vegetation are very acute at Savar, Ashulia, Tongi, and its adjoining areas. The different housing projects have been extended to these areas. With time, Tongi and Ashulia have become industrialized areas, and that results in the loss of vegetation in these areas significantly. Toward the northeast, some parts of vegetat cover have also been lost over years. Besides, small-scale vegetation losses have been seen in different parts of the river.

The urban areas were increased about three times from 1989 (209 ha) to 2019 (589 ha). It is clear that, in 1989, the urban growth was in the northwestern part of the Turag River as a mostly industrialized and commercial zone. Then, the urban growth has been expanded toward the eastern part of the Turag River. In 2019, urbanization has reached the furthest part of the eastern and northern parts of Dhaka city, which are mostly encroaching the areas surrounding the rivers Fig. 4 . As the developed areas were mostly vegetated and wetlands earlier, so, this kind of unplanned urbanization has greatly degraded the living condition as well as the ecosystem of the surrounding rivers of Dhaka city.

Bhattacharya et al. [42] found a similar trend using unsupervised classification techniques that shows rapid

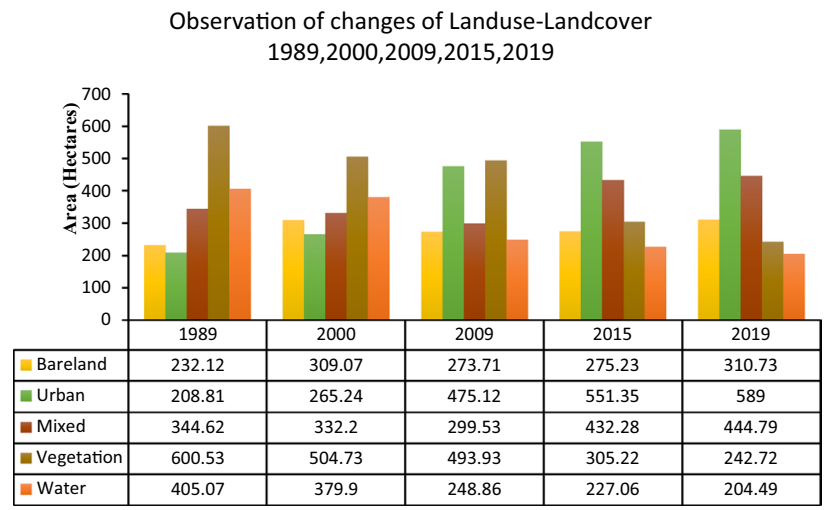

Fig. 4 Histogram distribution showing the changes in LULC of the study area from 1989 to 2019 urbanization replacing huge vegetated area and bare land in and around Dhaka city. Shapla et al. [43] inferred that the local economy especially unplanned urban and industrial development significantly facilitates the reduction of huge agricultural land in Gazipur which is very close to the study area. Mahmud-ul-Islam [44] conducted a similar study in the Buriganga river which is also located in Dhaka city concerning LULC and water management issues for ensuring a sustainable environment. He reported that the Buriganga River is becoming extremely polluted owing to the careless dumping of industrial effluents, and household waste claiming the rapid industrialization and urbanization. Turag and Buriganga are the most vulnerable urban rivers in Bangladesh.

\subsubsection{LULC mapping based on NDVI}

From the NDVI thematic classified maps, it has been identified that the vegetation was reduced by about $60 \%$ from 1989 (about $858 \mathrm{ha}$ ) to 2019 (about $346 \mathrm{ha}$ ) in the study area. There was a gradual decrease in vegetation cover from the year 1989 to 2019 Table 2. Vegetation cover toward southwest and southeast near Savar, Aminbazar bridge, Mirpur road, and other low-lying areas have suffered much destruction Fig. 5. These areas were marshy, grasslands where housing projects have been developed to meet up the extended population Fig. 6. Toward the northwest and northeast part of the river near Ashulia, Tongi, and Uttars, vegetated areas have also been reduced with similar scenarios due to urbanization. Trotter et al. [45] determined the effects of rapid urbanization in Dhaka megacity using NDVI-based LULC. He found a close relation between decreased vegetation and increased urbanization. Singh et al. [46] utilized NDVI-based LULC classification approach in lower Assam, India. He pointed out that a significant amount of forest degraded due to urbanization. The present study also suggests the simultaneous increase of urban areas and the decrease in vegetation cover.

\subsubsection{LULC mapping based on NDWI}

Results from NDWI analysis show that the water bodies are reduced gradually by about $65 \%$ from 1989 (765 ha) to 2019 (about $267 \mathrm{ha}$ ) Table 3. From the thematic NDWI map of 1989 , it is identified that there is huge water near

Table 2 Summary results of area coverage of LULC classes based on the NDVI of the study area from 1989 to 2019

\begin{tabular}{|c|c|c|c|c|c|c|c|c|c|c|}
\hline \multirow[t]{2}{*}{ Class name } & \multicolumn{2}{|l|}{1989} & \multicolumn{2}{|l|}{2000} & \multicolumn{2}{|l|}{2009} & \multicolumn{2}{|l|}{2015} & \multicolumn{2}{|l|}{2019} \\
\hline & Area (ha) & Area (\%) & Area (ha) & Area (\%) & Area (ha) & Area (\%) & Area (ha) & Area (\%) & Area (ha) & Area (\%) \\
\hline Land & 1026.27 & 57.29 & 1266.01 & 70.68 & 1414.16 & 78.95 & 1473.39 & 82.29 & 1524.49 & 85.1 \\
\hline Water & 764.91 & 42.7 & 525.71 & 29.31 & 377.02 & 21.04 & 317.19 & 17.71 & 266.69 & 14.89 \\
\hline
\end{tabular}


NDVI of Study Area from 1989 to 2019

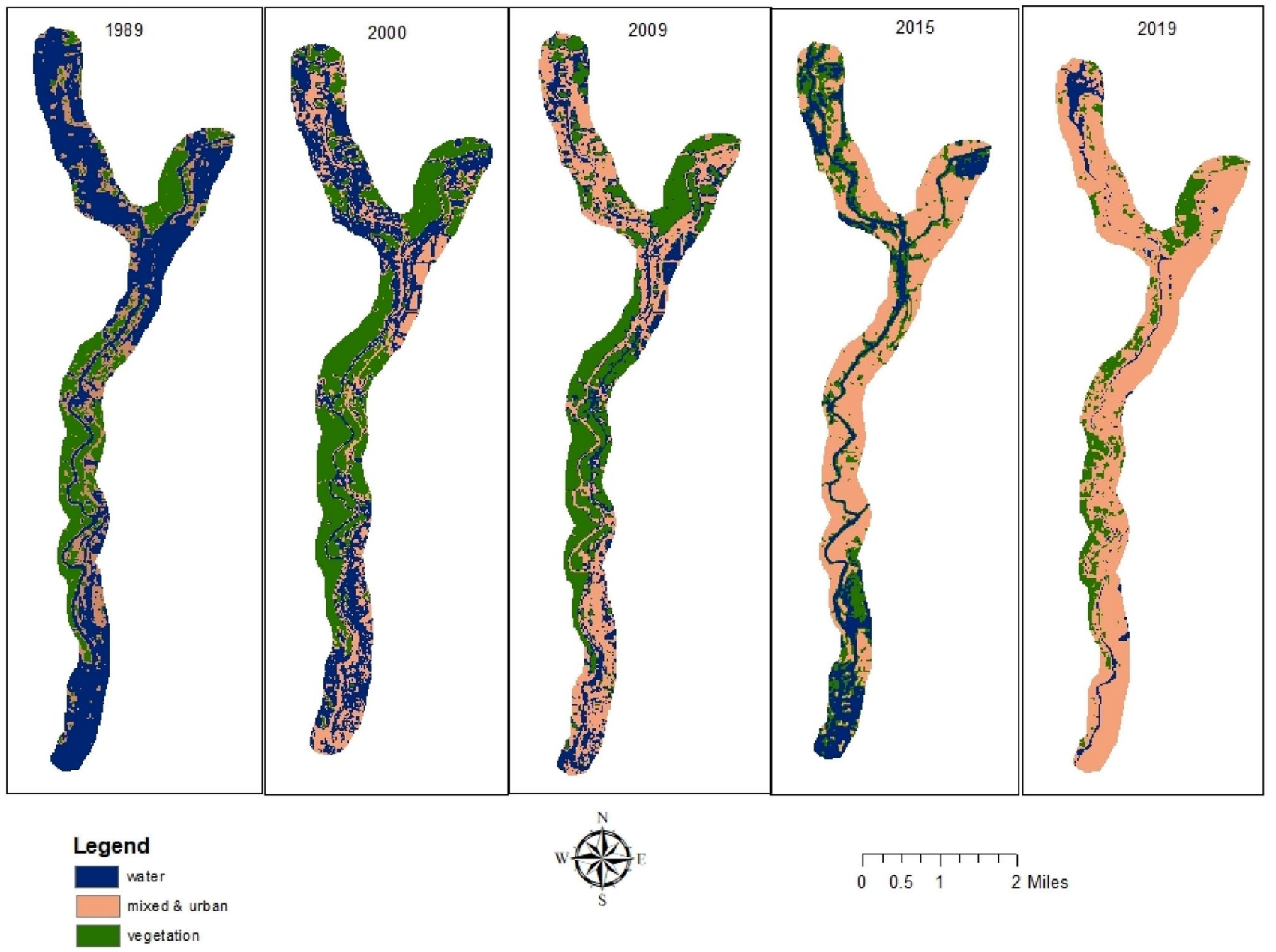

Fig. 5 Spatial distribution of LULU based on NDVI from 1989 to 2019

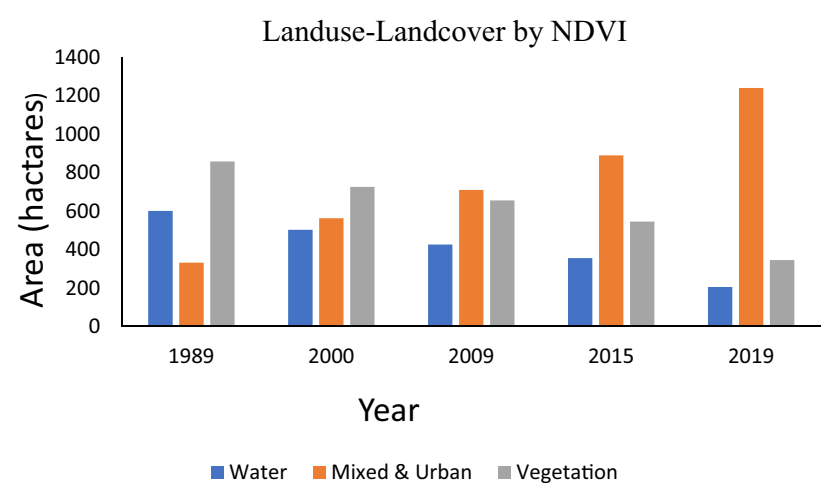

Fig. 6 Area coverage of LULC based on NDVI from 1989 to 2019

to Ashulia western part of the Turag River. At that time, the water bodies are also significant at Savar near to Gabtoli bridge where Turag River joins with Buriganga river
Fig. 3. In 2000, water bodies have been decreased rapidly. In 2019, the water bodies of the Turag River reduced in a great amount about $65 \%$ from 1989 to 2019 Fig. 7. The study suggests that the Turag River has dried out mostly in 2019 in comparison with 1989 Fig. 8. Rapid urbanization is the main cause of this reduction of water. In course of time, many industries have been built up at Savar, Ashulia, and Tongi, which is the possible reason behind the reduction of the water bodies of the Turag River. Results of all three methods show that the water bodies have been declined significantly about $60-66 \%$ Fig. 9.

Ullah and Enan [47] used NDVI and NDWI index for mapping water bodies and vegetation cover in Dhaka city. They found that from 1991 to 2016 built-up area increased $120 \mathrm{Km}^{2}$ with a simultaneous reduction of about $82 \mathrm{Km}^{2}$ water bodies. Mia et al. [48] also suggested identical findings in their research conducted in Dhaka city by NDVI indices. Gazi et al. [49] used NDWI 
Table 3 Summary results of area coverage of LULC classes based on NDVI of the study area from 1989 to 2019

\begin{tabular}{|c|c|c|c|c|c|c|c|c|c|c|}
\hline \multirow[t]{2}{*}{ Class name } & \multicolumn{2}{|l|}{1989} & \multicolumn{2}{|l|}{2000} & \multicolumn{2}{|l|}{2009} & \multicolumn{2}{|l|}{2015} & \multicolumn{2}{|l|}{2019} \\
\hline & Area (ha) & Area (\%) & Area (ha) & Area (\%) & Area (ha) & Area (\%) & Area (ha) & Area (\%) & Area (ha) & Area (\%) \\
\hline Water & 600.78 & 33.54 & 502.93 & 28.07 & 425.65 & 23.76 & 255.23 & 19.83 & 205.24 & 11.45 \\
\hline Mixed and Urban area & 332.21 & 18.54 & 562.67 & 39.62 & 709.75 & 39.62 & 890.1 & 49.69 & 1240.31 & 69.24 \\
\hline Vegetation & 858.19 & 47.68 & 752.58 & 40.51 & 655.85 & 36.61 & 545.85 & 30.47 & 345.63 & 19.29 \\
\hline
\end{tabular}

\section{NDWI Map of the study area from 1989 to 2019}

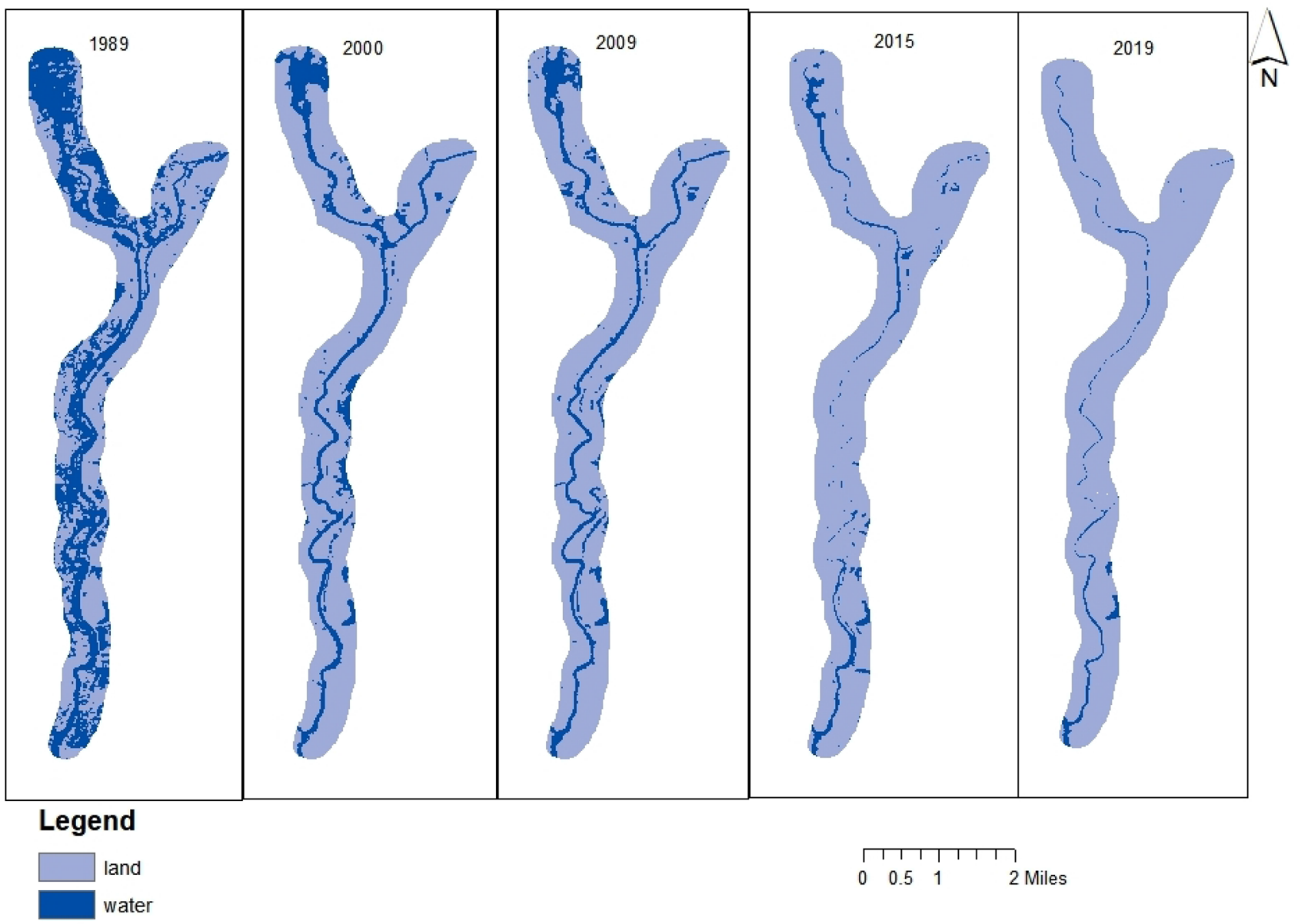

Fig. 7 Spatial distribution of LULU based on NDWI from 1989 to 2019

indices for mapping LULC for the last 47 years around two major river confluences in Bangladesh and found a significant decrease in water bodies around the confluences. The present study has utilized unsupervised, NDVI, and NDWI classification and compared the results to achieve maximum accuracy of LULC classification.

\subsection{Water quality analysis}

\subsubsection{Physical properties of water}

The $\mathrm{pH}$ value of collected surface water samples ranges from 6.87 to 8.44 . The average $\mathrm{pH}$ value is 7.54 . The lowest 


\section{observation of LULC by NDWI classification of $1989,2000,2009,2015,2019$}

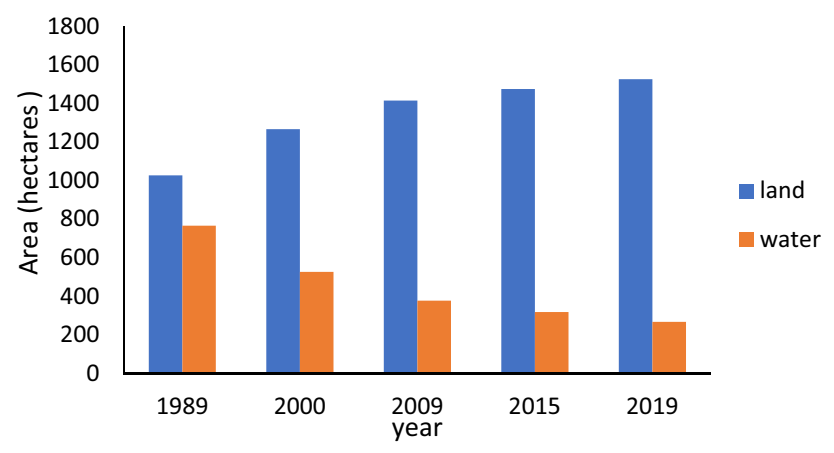

Fig. 8 Comparison of LULC classes based on NDWI from 1989 to 2019

Changes of water bodies by Unsupervised, NDVI, NDWI

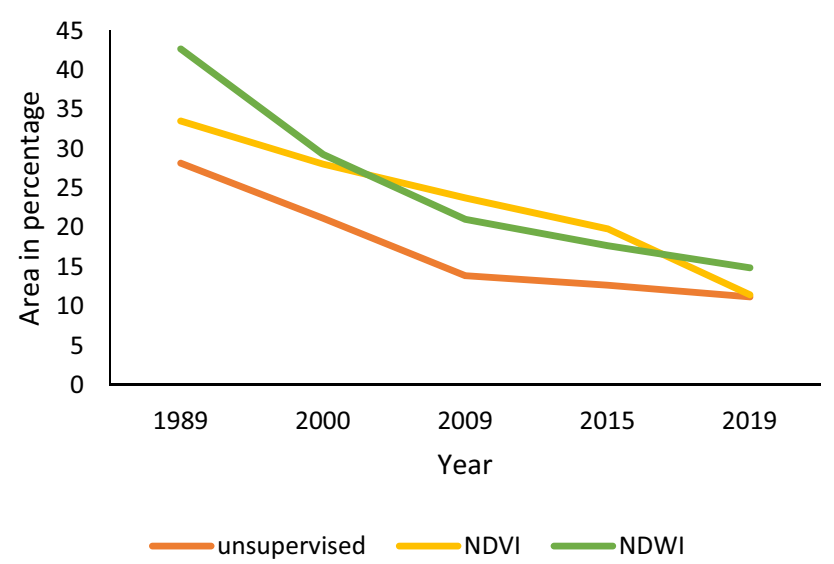

Fig. 9 Changes of water bodies among various methods out of the total study area

$\mathrm{pH}$ is near Gabtoli Bridge Ghat 6.87 and the highest value is near the Rupnagar bus stand which is 8.44 Table 4 . For inland surface, water $\mathrm{pH}$ standard limits are 6.5-8.5 [50]. The field observation shows that the $\mathrm{pH}$ value of the Turag River is within the standard limit. Halder and Islam [51] documented $\mathrm{pH}$ ranged from 6.14 to 8.79 which is close to the $\mathrm{pH}$ obtained by the present study.

EC value of the Turag River is 808 to $1192 \mu \mathrm{s} / \mathrm{cm}$. The average value of EC is $1062.14 \mu \mathrm{s} / \mathrm{cm}$. The highest value of EC is $1493 \mu \mathrm{s} / \mathrm{cm}$ which is near Ashulia Chowrasta. The lowest value of EC is $808 \mu \mathrm{s} / \mathrm{cm}$ which is near to Rupnagar bus stand (Table 4). For inland surface water, standard electrical conductivity is $1200 \mu \mathrm{S} / \mathrm{cm}$ [52]. The flow of the river increases in the monsoon season, which may dilute the river water, whereas in the dry season, the flow of the river declines which increases the EC. The samples have been collected in pre-monsoon (March), so the EC of the samples is high. Industries discharge into the river is responsible for high EC.

The measured Eh value from upstream to downstream is -31 to $-150 \mathrm{mV}$. The average value of Eh is $104.78 \mathrm{mV}$. The highest value of Eh is $-150 \mathrm{mV}$ which is near Ashulia Bridge, and the lowest value is - $28 \mathrm{mV}$ near the Rupnagar bus stand. The $\mathrm{pH}$ and $\mathrm{EC}$ are very close to the range obtained from the study [4]. The study documented the $\mathrm{pH}$ value ranged from 6.60 to 7.98 and EC from 160 to $1107 \mu \mathrm{s} / \mathrm{cm}$. He found the ranges due to seasonal variations in the study area. After all, he also suggested that the Turag River water is not suitable for human consumption.

The TDS values of the Turag River from upstream to downstream are 406 (ppm) to 739 (ppm). The average value of TDS is 551.21 (ppm) (Table 4). The highest value is close to the Ashulia bus stand, and the lowest value is near to the Rupnagar bus stand. TDS standard for domestic water supplies is $500 \mathrm{ppm}$ by USPH, for drinking water is $1000 \mathrm{ppm}$, irrigation is $2000 \mathrm{ppm}$, and for industrial water is $1500 \mathrm{ppm}$ [53]. So, the TDS of Turag River water for domestic uses and drinking purses is at an alarming range. This alarming increase of TDS value was also reported by Meghla et al. [3] and Mobin et al. [33]. Halder and Islam [51] also found a higher TDS value that exceeded the standard permissible limit.

Based on the observation from 14 sampling locations, the highest water temperature has been recorded at $32.80^{\circ} \mathrm{C}$ and the lowest temperature is about $29.10^{\circ} \mathrm{C}$ and the average temperature of $30.05^{\circ} \mathrm{C}$. The increasing temperature is due to the cooling operations for the manufacturing of products by the industries besides the Turag River. Several studies reported that the quality of Turag River water is not within the acceptable limit for drinking and agricultural works [54], [3], [33]. Water quality analysis suggests that the Turag River is in danger due to industrial pollution [29]. Aktar and Moonajilin [34] indicated that Turag water pollution is at a critical point. Impacts of indoctrination and urbanization on the water quality has also been observed from recent studies in Bangladesh [55], [56], [57]

\subsubsection{Ion chemistry investigation}

The study confirming the consistency of the analytical results of ionic balance between cations and anions as it is within the acceptable limits (less than 10\%). Among the cations, $\mathrm{Na}+$ is dominant and the concentrations range between 85.43 and $247.60 \mathrm{mg} / \mathrm{l}$ with a mean of $172.91 \mathrm{mg} / \mathrm{l}$ (Fig. 10). The higher concentration of sodium may result due to the mixing of sodium-rich effluent from chemical, food, tannery, and leather industries. According to BDWS [58], the standard value of $\mathrm{Na}+$ is $200 \mathrm{mg} / \mathrm{l}$, 
Table 4 Showing the parameters describing physical properties of the Turag River water in different sampling points

\begin{tabular}{lllllll}
\hline Sample name & Location & $\mathrm{pH}$ & $\mathrm{EC}(\mu \mathrm{s} / \mathrm{cm})$ & $\mathrm{Eh}(\mathrm{mV})$ & TDS $(\mathrm{ppm})$ & $\begin{array}{l}\text { Tem- } \\
\text { perature } \\
\left({ }^{\circ} \mathrm{C}\right)\end{array}$ \\
\hline TR-1 & Gabtoli Bridge Ghat & & & & & 29.6 \\
TR-2 & Palpara Ghat & 6.87 & 1192 & -93 & 597 & 30.6 \\
TR-3 & Diabari Ghat & 7.29 & 1154 & -124 & 576 & 29.5 \\
TR-4 & Shahi Jama Masjid Nawaberbag & 7.40 & 1130 & -142 & 563 & 30.3 \\
TR-5 & Royel City Jame Masjid & 7.54 & 1147 & -117 & 573 & 30.5 \\
TR-6 & Dakshin Para Jame Masjid & 7.46 & 595 & -122 & 1192 & 30.7 \\
TR-7 & Nabil parking & 8.44 & 808 & -28 & 406 & 32.8 \\
TR-8 & Sluice gate & 7.69 & 787 & -112 & 392 & 29.4 \\
TR-9 & Birulia Bus Stand Ghat & 7.55 & 1146 & -119 & 576 & 29.6 \\
TR-10 & Ponchoboti Bus Stand & 7.93 & 1034 & -31 & 513 & 30.9 \\
TR-11 & Rustumpur Bus Stand Ghat & 7.64 & 1182 & -128 & 592 & 28.9 \\
TR-12 & Ashulia bus stop bridge & 7.86 & 1493 & -36 & 739 & 30.9 \\
TR-13 & Kamarpara Bus Stand & 7.42 & 962 & -134 & 472 & 30 \\
TR-14 & Tongi ljtema bridge & 7.15 & 886 & -150 & 442 & 29.1 \\
\hline
\end{tabular}

maximum samples were within the limit except for sample point TR-10 (near to Rustumpur) and TR-11 (near to BGMEA University). The concentration of $\mathrm{Ca}^{2+}$ ranges between 28.59 and $39.47 \mathrm{mg} / \mathrm{l}$ with an average value of $33.95 \mathrm{mg} / \mathrm{l}$. According to BDWS [58] and WHO [59], the acceptable limit of $\mathrm{Ca}^{2+}$ is $75 \mathrm{mg} / \mathrm{l}$, so all the water samples are within the acceptable limit. The concentration of $\mathrm{Mg}^{2+}$ is between 11.10 and $13.58 \mathrm{mg} / \mathrm{l}$ with a mean value of $12.27 \mathrm{mg} / \mathrm{l}$. The concentration of $\mathrm{K}^{+}$is between 5.21 and $13.26 \mathrm{mg} / \mathrm{l}$ (average $10.71 \mathrm{mg} / \mathrm{l}$ ). BDWS [58] acceptable limit for $\mathrm{K}^{+}$is $12 \mathrm{mg} / \mathrm{l}$. Four samples (TR-1, TR-2, TR-6, TR-11) exceed the limit. The major cation trend was $\mathrm{Na}^{+}>\mathrm{Ca}^{2+}>\mathrm{Mg}^{2+}>\mathrm{K}^{+}$.

Among the anions, $\mathrm{HCO}^{3-}$ is abundant and the concentration ranges between 165.45 and $388.87 \mathrm{mg} / \mathrm{l}$ with an average value of $286.63 \mathrm{mg} / \mathrm{l}$ (Fig. 11). The highest value is near to Ponchoboti bus stand. According to the Bangladesh Drinking Water Quality Standard [60], acceptable limit of $\mathrm{HCO}_{3}{ }^{-}$is $200 \mathrm{mg} / \mathrm{l}$, for Nitrate is $10 \mathrm{mg} / \mathrm{l}$, and for $\mathrm{Cl}^{-}$is $150-600 \mathrm{mg} / \mathrm{l}$. All the samples of the study area exceed the limit for $\mathrm{HCO}_{3}{ }^{-}$; only two samples, TR-13 and TR-14, are within the limit. $\mathrm{Cl}^{-}$varies between 54.81 and $194.07 \mathrm{mg} / \mathrm{l}$ with a mean value of $89.41 \mathrm{mg} / \mathrm{l}$. Concentration of $\mathrm{SO}_{4}{ }^{2-}$ is very high than the BMAC, ranging from 52.49 to $289.63 \mathrm{mg} / \mathrm{l}$ with a mean value of $192.78 \mathrm{mg} / \mathrm{l}$. The concentration of $\mathrm{SO}_{4}{ }^{2-}$ exceed the standard limit for samples TR-4, TR-5, TR-6, TR-8, TR-10, and TR-11. $\mathrm{NO}_{3}{ }^{-}$concentration ranges between 9.63 and $126.93 \mathrm{mg} / \mathrm{l}$ with a mean value of $57.80 \mathrm{mg} / \mathrm{l}$. All water samples of the study area exceed the limit except the sample TR-7. The major anion trend is $\mathrm{HCO}_{3}{ }^{-}>\mathrm{Cl}^{-}>\mathrm{SO}_{4}{ }^{2-}>\mathrm{NO}_{3}{ }^{-}$.

Minor $\left(\mathrm{Br}^{-}, \mathrm{PO}_{4}{ }^{3-} \& \mathrm{~F}^{-}\right)$and trace elements $\left(\mathrm{Fe}^{2+}, \mathrm{Mn}^{2+}\right)$ have been investigated from the collected water samples of the Turag River. The $\mathrm{PO}_{4}$ content in the collected water samples varies from 0.60 to $13.45 \mathrm{mg} / \mathrm{l}$ with a mean value of $5.89 \mathrm{mg} / \mathrm{l}$ (Fig. 12). The permissible limit of phosphate for irrigation water is $2.00 \mathrm{mg} / \mathrm{l}$ [61]. So, $\mathrm{PO}_{4}{ }^{2-}$ values in all water samples except TR-7 were above the permissible limit for irrigation that might be harmful for crop production. $\mathrm{F}^{-}$Concentration ranges between 0.07 and $0.13 \mathrm{mg} / \mathrm{l}$ with a mean value of $0.1 \mathrm{mg} / \mathrm{l}$. According to Environmental Protection Agency (EPA), WHO, and BWQS, the standard of $\mathrm{F}^{-}$is $2,1.5$, and $1 \mathrm{mg} / \mathrm{l}$, respectively, and from the analysis, it is found that the samples are within the limit. Concentration of $\mathrm{Br}^{-}$was between 0.07 and $1.58 \mathrm{mg} / \mathrm{l}$ with a mean value to $0.87 \mathrm{mg} / \mathrm{l}$ (Fig. 12). Water samples collected from the Turag River contained comparatively less amount of iron (Fe), and the amount varies from 0.07 to $1.14 \mathrm{mg} / \mathrm{l}$ with a mean value of $64 \mathrm{mg} / \mathrm{l}$. According to the Bangladesh Water Quality Standard [60], the standard value is $0.3-1 \mathrm{mg} / \mathrm{l}$. All samples are within the limit except TR-1 and TR-14. The major sources of iron are pharmaceuticals, chemicals, pesticides, and industries around the study area. The concentration of $\mathrm{Mn}$ in water samples of the Turag River ranges from .006 to $.47 \mathrm{mg} / \mathrm{l}$ with a mean value of $.22 \mathrm{mg} / \mathrm{l}$. According to WHO (0.1 mg/l), all samples exceed the limit except TR-7 and TR-10.

Islam et al. [38] documented that metal concentration in Turag River water is increasing day by day due to solid waste dumping and industrial effluents. Tahmina et al. [62] also showed that most of the physicochemical parameters of Turag River water exceed the standards suggested by WHO [59]. Banu et al. [63] analyzed Turag River sediments to assess heavy metal concentration. Interestingly, he also found the frightening upraise of heavy metals in Turag River water sediments that were settled from river water suspension. 


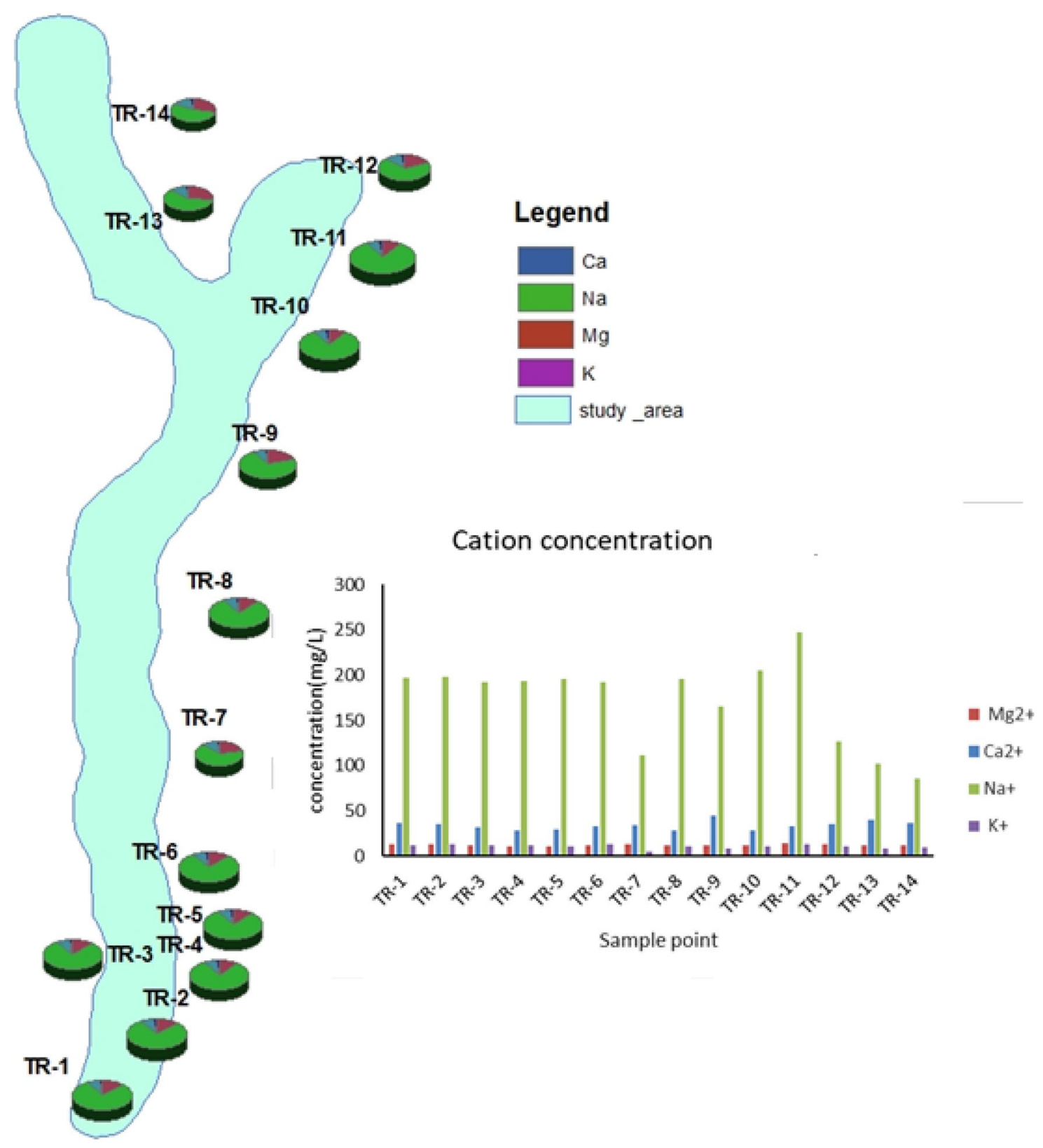

Fig. 10 Spatial distribution of cation concentration of collected water samples from the study area

\subsection{Land surface temperature (LST)}

LST is increasing day by day due to unplanned and rapid urbanization. The study area is within the temperature range of $15-20^{\circ} \mathrm{C}$ to $20-25^{\circ} \mathrm{C}$ from 1989 to 2019 , and indicates healthy vegetation during the year 1989 and 2000 (Fig. 13). There is a temperature range of $15-20^{\circ} \mathrm{C}$ in 2009 and 2015 which shows a lower temperature than any other years because of seasonal variations, solar radiation, and meteorological fact. Most of the higher temperatures have been observed in the land filled sites and other industrial zones. Using sand as a landfilling material is very much related to increased urban land surface temperature. The highest temperature range $31-36^{\circ} \mathrm{C}$ is shown in the LST Map of 2019 which indicates industrial zone and rapid urbanization. Satellite image-retrieved LST data values are lower than field observed in situ LST because the satellite images are the medium resolution (resampled $30 \mathrm{~m}$ ) and always gave an average pixel value (Fig. 14). In 1989, the highest temperature is $29.78^{\circ} \mathrm{C}$ near Ashulia Bridge and the lowest LST temperature is about $27.13^{\circ} \mathrm{C}$ near to Royal city area which is at Mirpur road. In 2000, the highest 


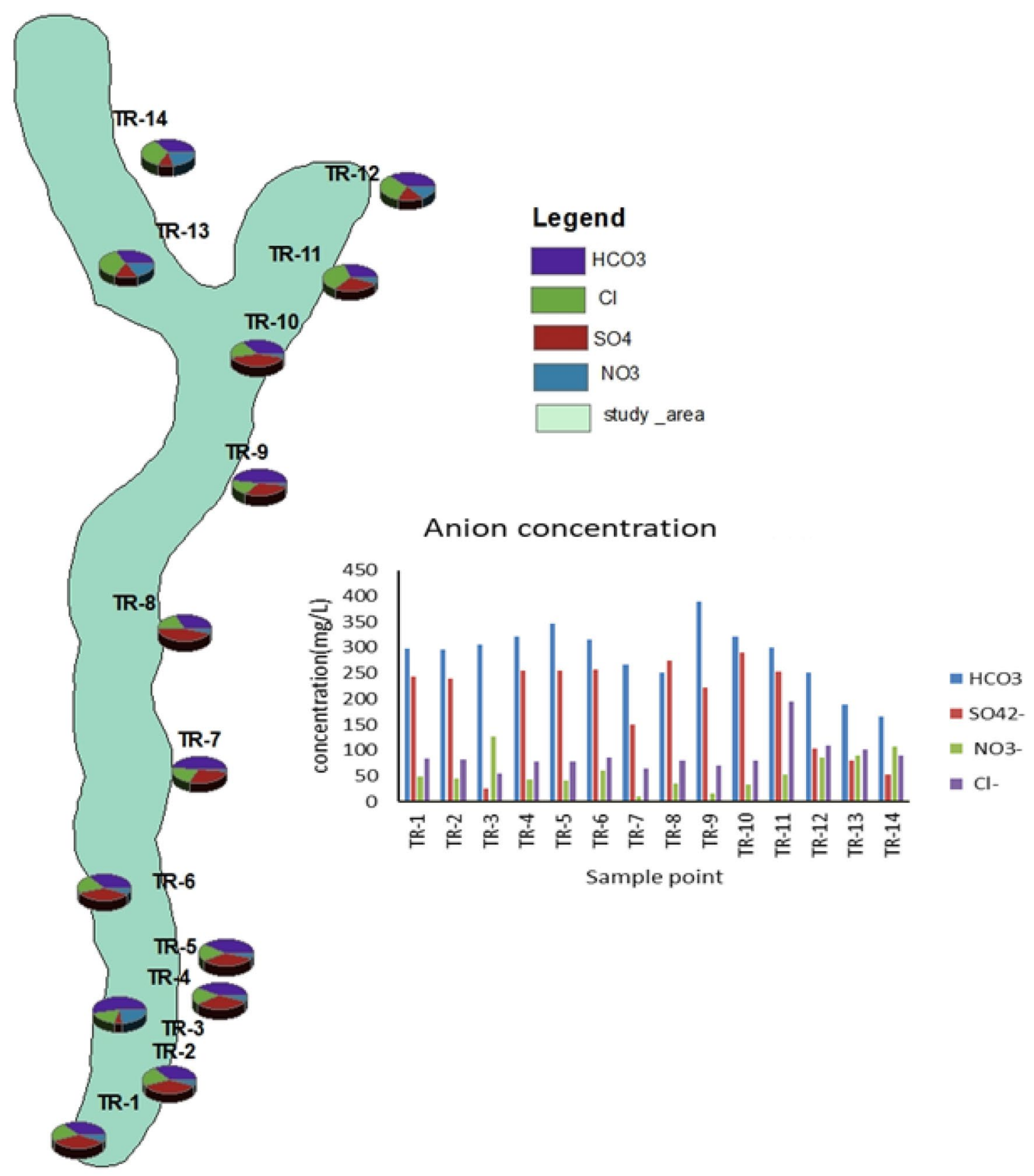

Fig. 11 Spatial distribution of anions concentration of collected water samples from the study area

temperature is about $25.48^{\circ} \mathrm{C}$ adjacent to Ashulia Bridge and the lowest temperature is about $20.35^{\circ} \mathrm{C}$ near Diabari Bazar Ghat.

The highest and lowest temperature range value is about $28.97-23.33^{\circ} \mathrm{C}, 30.32-24.07{ }^{\circ} \mathrm{C}, 30.19-25.68{ }^{\circ} \mathrm{C}$, respectively, in 2009, 2015, and 2019. The ground observation shows that the temperature is highest at $30.19^{\circ} \mathrm{C}$ in 2019 near to Ponchoboti bus stand and Ashulia Beribadh and lowest at $28.9^{\circ} \mathrm{C}$ near to Rustumpur bus stand. From the image processed data of 2019, it shows that the highest temperature of the water is 30.19 near Ashulia and the lowest temperature is $26.07{ }^{\circ} \mathrm{C}$ near to Rustumpur bus stand. The average temperature of the water from filed observed data is $30.05^{\circ} \mathrm{C}$ and from image processed data is about $28.32{ }^{\circ} \mathrm{C}$. Ferdous and Rahman [64] also suggested the positive correlation between urban expansion and increasing land surface temperature (LST) in Dhaka city. Chaudhuri and Mishra [65] compared LST and landcover dynamics both in India and Bangladesh in the Ganges-Brahmaputra delta. They urged proper LULC 


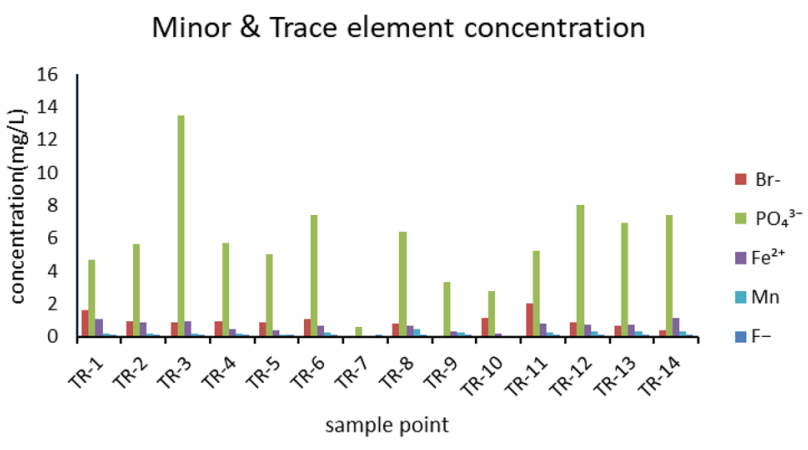

Fig. 12 Concentration of minor and trace elements $(\mathrm{mg} / \mathrm{l})$ within the collected water samples from the Turag River

Comparison between in situ and satellite retrieved LST

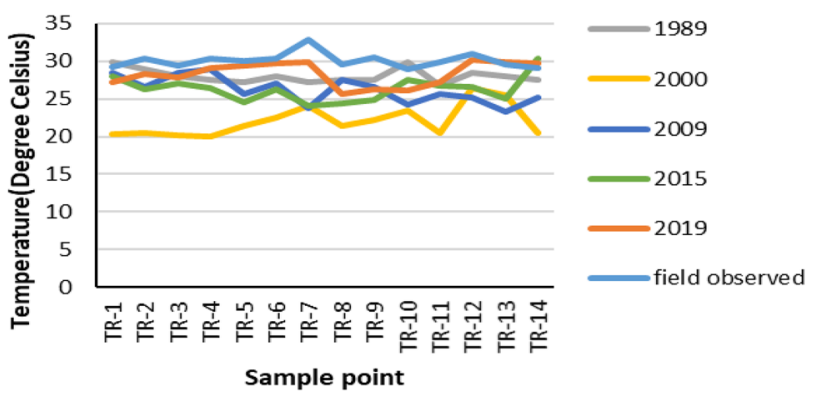

Fig. 13 Satellite image-retrieved LST and in situ measured temperature in the sampling points

management within the delta and river floodplain to protect environmental health and reduce LST. LST of Turag River floodplain also suggests proper LULC management to protect Turag environmental health.

\subsection{Relation among LULC, LST, and water quality- quantity}

LULC mapping by time series analysis from satellite images suggests that LULC pattern controls the water quality in different parts of the river. The results show that Turag flood plain area has been experiencing an increase in urban and industrial growth, but forest and grassland are rapidly reduced. This increasing urban expansion and unplanned industrialization are responsible for discharging huge municipal and untreated effluents to the river water (Fig. 15). These development activities are destroying the natural river ecosystem by huge water withdrawal and the infilling river area. It is evident that urban development is more intensive in the southern downstream part of the Turag River. Water samples collected from downstream of the study area show a high concentration of specific cations and anions with minor and trace elements in comparison with other parts of the river. It can be validated by using water quality data from the respective year of LULC map. From 1989 to 2019, the river floodplain area has been undergone a huge change in LULC showing the enlargement of the industrial zone and urbanization with simultaneous reduction of water bodies and vegetation. This human-induced LULC change has been triggered by the LST of the floodplain area. The high LST has also been observed in the river water due to the untreated hot wastewater discharge into the river. Furthermore, the water quality deteriorated owing to the unplanned industrialization on the Riverbanks.

Rahman et al. [8] and Banu et al. [63] studied the physicochemical properties of Turag River water. They found low EC and TDS values along with less cation and anionic concentration compared to the results of the present study. We can correlate this concentration with LULC map of 2009 or 2015. It can be better represented by correlating water quality data of 1989, 2000, and 2009 with the LULC map of the respective years. However, there is a strong correlation between LULC and water quality.

Similarly, the LST of the study area was examined due to the positive correlation between urbanization and increasing LST. It can be validated by using LST in the flood plain area. The increasing LST in the flood plain area is owing to the rapid industrialization. LST is higher in urbanized and industrialized regions rather than bare lands and vegetated areas. Urbanization is most prominent in the upstream region, but industrial developments are more evident in the downstream regions. Both areas around the river flood plain show abnormally higher LST. Interestingly, the LST of the study area provides an important clue to the presence of industrial effluents in the river channel. Generally, water shows a lower temperature than terrestrial regions [24], Alavipanah et al. [66] but different parts of the Turag River channel mainly in the downstream area demonstrate higher LST. In situ water temperature data from field observation also suggest warmer water in this region.

\section{Conclusion}

The study has been attempted to evaluate the changes in water quality and quantity with LULC in the floodplains of the Turag River. The classification approaches depict that the water body is decreasing day by day. It has also been observed that the vegetated area has been decreased over these years which are about $60 \%$ in terms of percentage. Urban growth and simultaneously reduced vegetation are responsible for degrading water quality in the Turag River. The water is highly polluted and detrimental to human health and the aquatic 


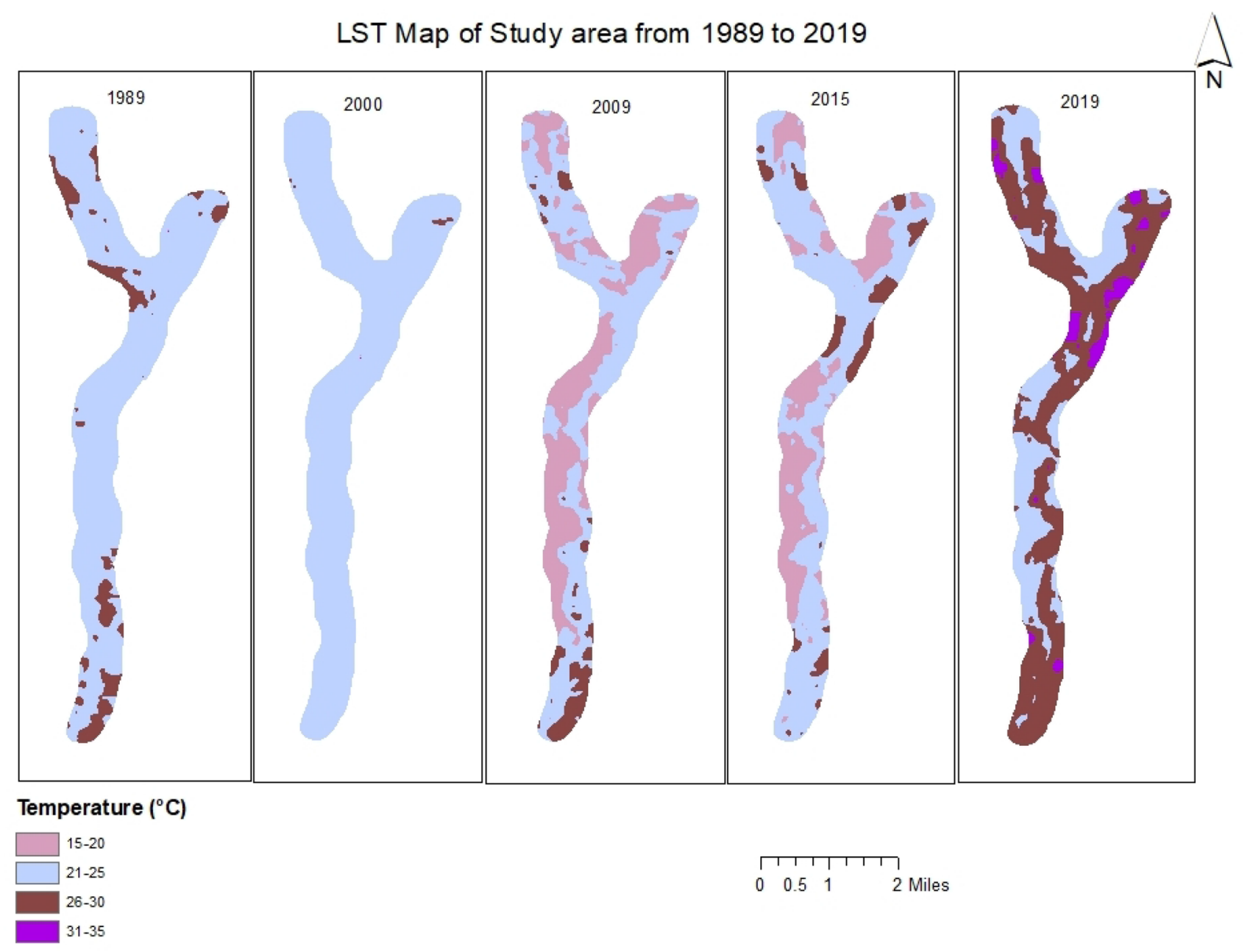

Fig. 14 Comparison and distribution of retrieved LST from 1989 to 2019 using multispectral Landsat satellite images

ecosystem. It is very crucial to revive the river by reducing the degree of pollution by implementing laws and raising public awareness. Among the physicochemical parameters, nitrate \& bicarbonate exceeded the acceptable limit that is due to the unplanned discharge of various industrial effluents. The study suggests that the water is not safe for drinking and household uses and must be treated before this kind of utilization. Based on the findings of this research, the level of pollution should be reduced by taking effective measures immediately and more concentration should be paid to the environmental problems of the River. It is very crucial to revive the river by reducing anthropogenic activities by implementing laws and raising public awareness. It is only possible by creating awareness among the people regarding the consequences of this deteriorating environmental condition of this river. Otherwise, it will follow the fate of the Buriganga River, Dhaka, that is the most polluted river in Bangladesh. The outputs of the study will play a significant role in urban river management. The study also provides a key message to the policymakers regarding the necessity of proper and sustainable floodplain management. 


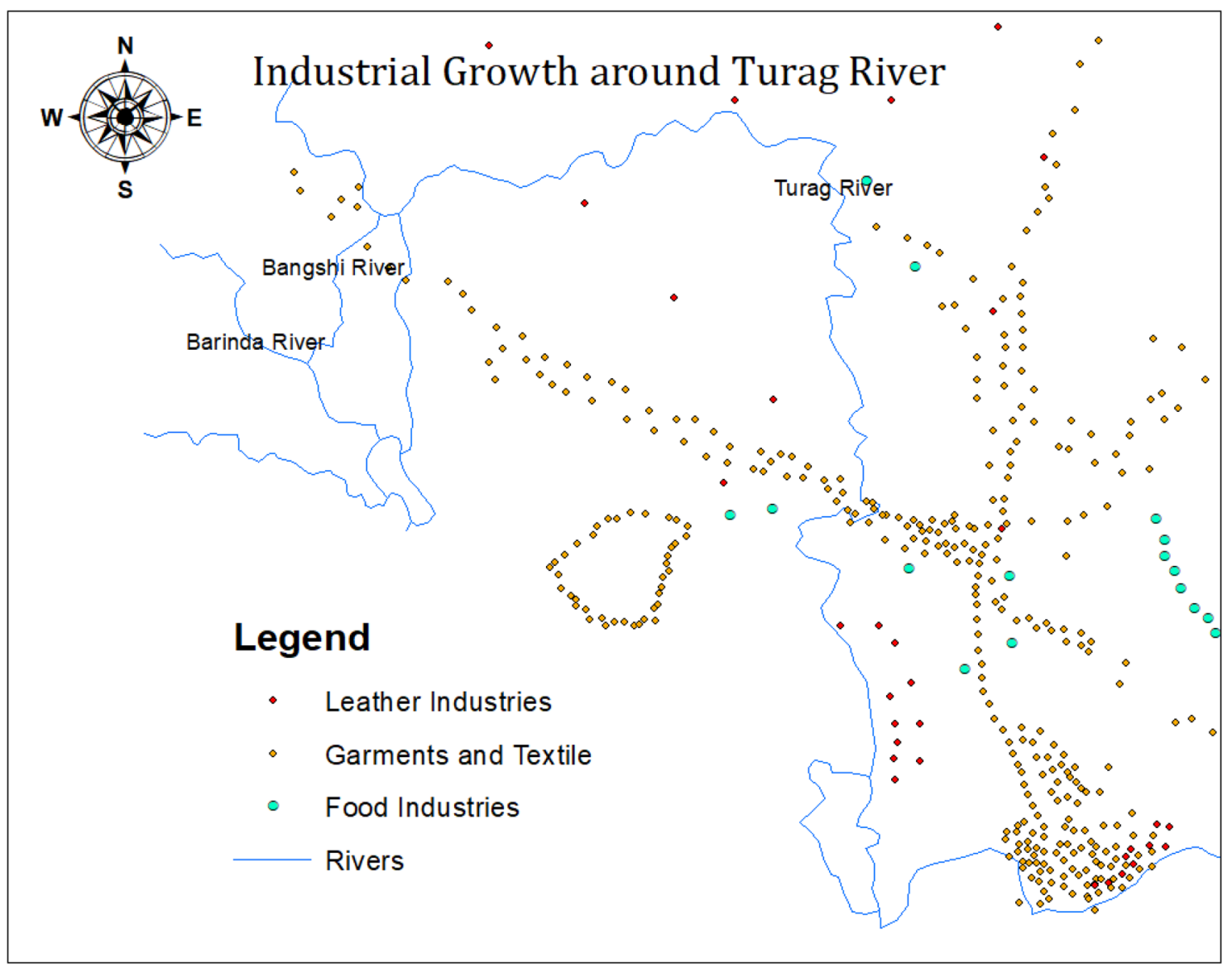

Fig. 15 Spatial distribution of leather, garments, textile, and food industries around the Turag River

Acknowledgements The authors are profoundly grateful to the Department of Geology, University of Dhaka for providing laboratory facilities throughout the study. We must acknowledge the anonymous reviewers for their valuable suggestions and recommendations.

\section{Compliance with ethical standards}

Conflict of interest The authors declare that they have no conflict of interest

Open Access This article is licensed under a Creative Commons Attribution 4.0 International License, which permits use, sharing, adaptation, distribution and reproduction in any medium or format, as long as you give appropriate credit to the original author(s) and the source, provide a link to the Creative Commons licence, and indicate if changes were made. The images or other third party material in this article are included in the article's Creative Commons licence, unless indicated otherwise in a credit line to the material. If material is not included in the article's Creative Commons licence and your intended use is not permitted by statutory regulation or exceeds the permitted use, you will need to obtain permission directly from the copyright holder. To view a copy of this licence, visit http://creativecommons .org/licenses/by/4.0/.

\section{References}

1. Uddin HM (2005) Initial environmental impact assessment of the Turag-Buriganga naval transport. M.Sc. dissertation (unpublished), Department of Geography and Environment, Jahangirnagar University, Dhaka

2. BCAS (Bangladesh Center for Advance Studies) (2000) Pollution study. Management of aquatic ecosystem through community husbandry (MACH), Dhaka, Bangladesh. Banglapedia, 2019

3. Meghla NT, Islam MS, Ali MA, Nargis S (2013) Assessment of physicochemical properties of water from the Turag River in Dhaka City, Bangladesh. Int J Curr Microbiol Appl Sci 2(5):110-122

4. Rahman AKML, Islam M, Hossain MZ, Ahsan MA (2012) Study of the seasonal variations in Turag river water quality parameters. Afr J Pure Appl Chem 6(10):144-148

5. DoE (Department of Environment) (2001) The general over view of pollution status of river of Bangladesh. Government of the People's Republic of Bangladesh, Ministry of Environment and Forest, Department of Environment, Dhaka, Bangladesh

6. Zaman MR, Hossain MM, Noman ASM, Rahman MS (2018) Effect of land use on water quality of the TURAG river. In: Proceedings of the 4 th International Conference on Civil Engineering for Sustainable Development (ICCESD), 9-11 February 2018, KUET, Khulna, Bangladesh (ISBN-978-984-34-3502-6)

7. Howladar FM, Chakma E, JahanKoley N, Islam S, Al Numanbakthan MA, Ahmed Z, Akter S (2020) The water quality and 
pollution sources assessment of Surma river, Bangladesh using, hydrochemical, multivariate statistical and water quality index methods. Groundw Sustain Dev 12:100523

8. Rahman MM, Howladar MF, Hossain MA, Muzemder ASH, Al Numanbakth MA (2020) Impact assessment of anthropogenic activities on water environment of Tillai River and its surroundings, Barapukuria Thermal Power Plant, Dinajpur Bangladesh. Groundw Sustain Dev 10:100310

9. Rahman M, Avtar R, Yunus AP, Dou J, Misra P, Takeuchi W, Kharrazi $A$ (2020) Monitoring effect of spatial growth on land surface temperature in Dhaka. Remote Sens 12(7):1191

10. Hasan MM, Ahmed MS, Adnan R, Shafiquzzaman M (2020) Water quality indices to assess the spatiotemporal variations of Dhaleshwari river in central Bangladesh. Environ Sustain Indic 8:100068

11. Haque MM, Niloy NM, Nayna OK, Fatema KJ, Quraishi SB, Park $\mathrm{JH}$, Tareq SM (2020) Variability of water quality and metal pollution index in the Ganges River, Bangladesh. Environ Sci Pollut Res 27(34):42582-42599

12. Kabir MH, Tusher TR, Hossain MS, Islam MS, Shammi RS, Kormoker T, Islam M (2020) Evaluation of spatio-temporal variations in water quality and suitability of an ecologically critical urban river employing water quality index and multivariate statistical approaches: a study on Shitalakhya river, Bangladesh. Hum Ecol Risk Assess An Int J. https://doi. org/10.1080/10807039.2020.1848415

13. Islam ARMT, Islam HT, Mia MU, Khan R, Habib MA, BodrudDoza M, Chu R (2020) Co-distribution, possible origins, status and potential health risk of trace elements in surface water sources from six major river basins, Bangladesh. Chemosphere 249:126180

14. Lee SW, Hwang SJ, Lee SB, Hwang HS, Sung HC (2009) Landscape ecological approach to the relationships of land use patterns in watersheds to water quality characteristics. Landsc Urban Plan 92(2):80-89

15. Zhao J, Lin L, Yang K, Liu Q, Qian G (2015) Influences of land use on water quality in a reticular river network area: a case study in Shanghai, China. Landsc Urban Plan 137:20-29

16. Qiao C, Luo J, Sheng Y, Shen Z, Zhu Z, Ming D (2012) An adaptive water extraction method from remote sensing image based on NDWI. J Indian Soc Remote Sens 40(3):421-433

17. McFeeters SK (2013) Using the normalized difference water index (NDWI) within a geographic information system to detect swimming pools for mosquito abatement: a practical approach. Remote Sens 5(7):3544-3561

18. Gómez-Sapiens MM, Jarchow CJ, Flessa KW, Shafroth PB, Glenn EP, Nagler PL (2020) Effect of an environmental flow on vegetation growth and health using ground and remote sensing metrics. Hydrol Process 34(8):1682-1696

19. Gaafar M, Mahmoud SH, Gan TY, Davies EG (2020) A practical GIS-based hazard assessment framework for water quality in stormwater systems. J Clean Prod 245:118855

20. Gazi MY, Hossain F, Sadeak S, Uddin MM (2020) Spatiotemporal variability of channel and bar morphodynamics in the GoraiMadhumati River, Bangladesh using remote sensing and GIS techniques. Front Earth Sci. https://doi.org/10.1007/s1170 7-020-0827-z

21. Gazi MY, Roy H, Mia MB, Akhter SH (2020) Assessment of morpho-dynamics through geospatial techniques within the padma-meghna and ganges-jamuna river confluences Bangladesh. KN J Cartogr Geogr Inf. https://doi.org/10.1007/s4248 9-020-00051-2

22. Chawla I, Karthikeyan L, Mishra AK (2020) A review of remote sensing applications for water security: quantity, quality, and extremes. J Hydrol 585:124826
23. Shen Z, Hou X, Li W, Aini G (2014) Relating landscape characteristics to non-point source pollution in a typical urbanized watershed in the municipality of Beijing. Landsc and Urban Plan 123:96-107

24. Tan J, Yu D, Li Q, Tan X, Zhou W (2020) Spatial relationship between land-use/land-cover change and land surface temperature in the Dongting Lake area, China. Sci Rep 10(1):1-9

25. Somvanshi S, Kunwar P, Singh NB, Shukla SP, Pathak V (2012) Integrated remote sensing and GIS approach for water quality analysis of Gomti river, Uttar Pradesh. Int J Environ Sci 3(1):62-74

26. Gazi MY, Mowsumi TJ, Ahmed MK (2020) Detection of coral reefs degradation using geospatial techniques around saint martin's, Island Bay of Bengal. Ocean Sci J. https://doi.org/10.1007/s1260 1-020-0029-3

27. Thakur S, Maity D, Mondal I, Basumatary G, Ghosh PB, Das P, De TK (2020) Assessment of changes in land use, land cover, and land surface temperature in the mangrove forest of Sundarbans, northeast coast of India. Environ Dev Sustain. https://doi. org/10.1007/s10668-020-00656-7

28. Akter T, Gazi MY, Mia MB (2021) Assessment of land cover dynamics, land surface temperature, and heat island growth in northwestern Bangladesh using satellite imagery. Environ Proc

29. Rampley CPN, Whitehead PG, Softley L, Hossain MA, Jin L, David J, Peters R (2020) River toxicity assessment using molecular biosensors: heavy metal contamination in the Turag-BaluBuriganga river systems, Dhaka, Bangladesh. Sci Total Environ 703:134760

30. Baki MA, Shojib MFH, Sehrin S, Chakraborty S, Choudhury TR, Bristy MS, Khan MF (2020) Health risk assessment of heavy metal accumulation in the Buriganga and Turag River systems for Puntius ticto, Heteropneustes fossilis, and Channa punctatus. Environ Geochem Health 42(2):531-543

31. Khan R, Islam MS, Tareq ARM, Naher K, Islam ARMT, Habib MA, Ullah AA (2020) Distribution, sources and ecological risk of trace elements and polycyclic aromatic hydrocarbons in sediments from a polluted urban river in central Bangladesh. Environ Nanotechnol Monit Manage 14:100318

32. Whitehead PG, Bussi G, Peters R, Hossain MA, Softley L, Shawal S, Alabaster G (2019) Modelling heavy metals in the Buriganga River system, Dhaka, Bangladesh: impacts of tannery pollution control. Sci Total Environ 697:134090

33. Mobin MN, Islam MS, Mia MY, Bakali B (2014) Analysis of physicochemical properties of the Turag River water, Tongi, Gazipur in Bangladesh. J Environ Sci Nat Resour 7(1):27-33

34. Aktar P, Moonajilin MS (2017) Assessment of water quality status of Turag River due to industrial effluent. Int J Eng Inform Syst (IJEAIS) 1(6):105-118

35. Zakir HM et al (2012) Heavy metals and major ionic pollution assessment in waters of Midstream of Karatoa River Bangladesh. J Environ Sci Nat Resour 5(2):149-160

36. Islam JB, Akter S, Bhowmick AC, Uddin MN, Sarkar M (2018) Hydro-environmental pollution of Turag river in Bangladesh. Bangladesh J Sci Ind Res 53(3):161-168

37. Chowdhury AG, Chowdhury A (2004) An assessment of water resources and flood management and development in Dhaka city, Goethe-institute, Dhaka, Bangladesh. J Environ Sci Nat Resour 7(1):27-33

38. Islam MS, Tusher TR, Mustafa M, Mahmud S (2012) Effects of solid waste and industrial effluents on water quality of Turag River at Konabari industrial area, Gazipur, Bangladesh. J Environ Sci Nat Resour 5(2):213-218

39. Rabbani ML, Sarker S (2017) Pollution sources assessment of Turag River, Bangladesh. Volume 14:84-91

40. Rouse Jr JW, Haas RH, Deering DW, Schell JA, Harlan JC (1974) Monitoring the vernal advancement and retrogradation 
(Green Wave Effect) of natural vegetation. [Great Plains Corridor]. Geography 1:12-29

41. McFeeters SK (1996) The use of the normalized difference water index (NDWI) in the delineation of open water features. Int J Remote Sens 17(7):1425-1432

42. Bhattacharya R, Mia MB, Rahman MM, Ullah AW (2015) Monitoring landuse-landcover changes in dhaka city by integrating remote sensing and ground based observations. Dhaka Univ J Earth Environl Sci 4:13-20

43. Shapla T, Park J, Hongo C, Kuze H (2015) Agricultural land cover change in Gazipur, Bangladesh, in relation to local economy studied using Landsat images. Adv Remote Sens 4(03):214

44. Mahmud-ul-Islam S (2011) Land use change detection of the Buriganga River using GIS tools and its water management for promoting a sustainable environment.KTH, School of Architecture and the Built Environment (ABE), Land and Water Resources Engineering, Environmental Management and Assessment. LWR-EX-11-13, ISSN 1651-064X

45. Trotter L, Dewan A, Robinson T (2017) Effects of rapid urbanisation on the urban thermal environment between 1990 and 2011 in Dhaka Megacity, Bangladesh. AIMS Environ Sci 4(1):145-167

46. Singh RP, Singh N, Singh S, Mukherjee S (2016) Normalized difference vegetation index (NDVI) based classification to assess the change in land use/land cover (LULC) in Lower Assam, India. Int J Adv Remote Sens GIS 5(10):1963-1970

47. Ullah MS, Enan ME (2016) Landuse and land cover change in dhaka metropolitan area during. Orient Geogr 60(1\&2):12-20

48. Mia B, Bhattacharya R, Woobaidullah ASM (2017) Correlation and monitoring of land surface temperature, urban heat island with land use-land cover of Dhaka City using satellite imageries. Int J Res Geogr 3:10-20

49. Gazi MY, Rahman MZ, Uddin MM, Rahman FA (2020) Spatiotemporal dynamic land cover changes and their impacts on the urban thermal environment in the Chittagong metropolitan area, Bangladesh. GeoJournal. https://doi.org/10.1007/s1070 8-020-10178-4

50. EQS (Environmental Quality Standard) (1997) Government of the people's Republic of Bangladesh. Ministry of environment and forest, department of environment, Gazette, registere.d nr. DA-1, Dhaka, Bangladesh

51. Halder JN, Islam MN (2015) Water pollution and its impact on the human health. J Environ Hum 2(1):36-46

52. ECR (Environmental Conservation Rules) (1997) Government of the People's Republic of Bangladesh. Ministry of Environment and Forest, Department of Environment, Dhaka, Bangladesh, pp: 212-214

53. De AK (2005) Environmental Chemistry, 5th edn. New Age International $(P)$ Ltd, Daryagang

54. Hafizur RM, Nuralam HM, Rumainul IM (2017) Investigation of physicochemical parameter, heavy metal in Turag river water and adjacent industrial effluent in Bangladesh. J Sci Technol Environ Inform 5(1):347-360

55. Afrad MSI, Monir MB, Haque ME, Barau AA, Haque MM (2020) Impact of industrial effluent on water, soil and Rice production in Bangladesh: a case of Turag River Bank. J Environ Health Sci Eng. https://doi.org/10.1007/s40201-020-00506-8

56. Proshad R, Islam S, Tusher TR, Zhang D, Khadka S, Gao J, Kundu $S$ (2020) Appraisal of heavy metal toxicity in surface water with human health risk by a novel approach: a study on an urban river in vicinity to industrial areas of Bangladesh. Toxin Rev. https ://doi.org/10.1080/15569543.2020.1780615

57. Akbora MA, Rahmana MM, Bodrud-Dozac M, Morshedul M, Haquea M, Siddiqueb AB, Uddina MK (2020) Metal pollution in water and sediment of the Buriganga River, Bangladesh: an ecological risk perspective. Desalination Water Treat 193:284-301

58. BDWS (Bangladesh Drinking Water Standard) (1997) Bangladesh Gazette, Notification (Ministry of Environment and forest, Government of the Peoples Republic of Bangladesh, p 3124

59. WHO (2011) Guidelines for drinking-water quality, 4th edn. Switzerland, Geneva

60. Department of Environment (DOE) (1997) Bangladesh maximum admissible concentration: Industrial effluent quality standard for Bangladesh, Bangladesh Gazette

61. Ayers RS, Westcot DW (1985) Water quality for agriculture, vol 29. Food and Agriculture Organization of the United Nations, Rome

62. Tahmina B, Sujan D, Karabi R, Hena MK, Amin KR, Sharmin S (2018) Assessment of surface water quality of the Turag river in Bangladesh. Res J Chem Environ 22(2):49-56

63. Banu Z, Chowdhury MSA, Hossain MD, Nakagami KI (2013) Contamination and ecological risk assessment of heavy metal in the sediment of Turag River. An index analysis approach, Bangladesh

64. Ferdous J, Rahman MTU (2018) Temporal dynamics and relationship of land use land cover and land surface temperature in Dhaka, Bangladesh. In: Proceedings of the 4th international conference on civil engineering for sustainable development (ICCESD 2018) (pp. 9-11)

65. Chaudhuri G, Mishra NB (2016) Spatio-temporal dynamics of land cover and land surface temperature in Ganges-Brahmaputra delta: a comparative analysis between India and Bangladesh. Appl Geogr 68:68-83

66. Alavipanah SK, Haashemi S, Kazemzadeh-Zow A, Bloorani AD, Asadolah S (2016) Remotely sensed survey of Land surface temperature (LST) for evaluation of monthly changes of water consumption. In: 2nd Annual International Conference on Urban Planning and Property Development (UPPD 2016)

Publisher's Note Springer Nature remains neutral with regard to jurisdictional claims in published maps and institutional affiliations. 